\title{
Virtualni model školskog atrija
}

\author{
Nataša Boj, Aleksandra Tonković \\ III. osnovna škola Čakovec \\ Ivana pl. Zajca 24, Čakovec \\ natasa.boj@skole.hr, aleksandra.tonkovic@skole.hr
}

\begin{abstract}
Sažetak
U današnje vrijeme globalizacije, težnja suvremene nastave je poticati učenike na istraživački rad putem projektne nastave. U III. osnovnoj školi Čakovec realiziran je projekt izrade virtualnog modela školskog atrija nastao korelacijom predmeta Matematike, Informatike i Tehničke kulture. U projekt su bili uključeni učenici sedmih $i$ osmih razreda $(N=108)$ u šk. godini 2018./2019. Napravljena je analiza postojećeg stanja školskog atrija, te izrađen novi model primjenom informacijsko-komunikacijske tehnologije. Neposredno prije rada na projektu, ispitani su stavovi učenika o projektnoj nastavi u III. OŠ Čakovec. Uzorak je obuhvatio sve dostupne učenike $(N=202, M=52 \%, \breve{Z}=48 \%)$ od petog do osmog razreda. U tu svrhu, proveden je anketni upitnik. Analizirani su $i$ prikupljeni podaci statistički obrađeni (kvalitativno i kvantitativno, te prikazani grafički). Stavovi učenika su pokazali da je projektna nastava više zastupljena u izbornoj nastavi. Kroz rad na projektu učenici su primijenili matematičko-informatička znanja i vještine, kao i znanja $i$ vještine iz predmeta Tehničke kulture. Aktivnosti učenika su bile: uočavanje određenih površina atrija (travnate, drvene i kamene) i izračunavanje površina istih u cilju izrade troškovnika, izrada analognog i digitalnog tlocrta u umanjenim mjerilima, izrada troškovnika postojećih materijala na temelju prikupljenih podataka s interneta. Nadalje, izrađen je virtualni model novog atrija primjenom informacijsko-komunikacijske tehnologije. 3D modeliranjem izrađeni su novi elementi za školski atrij - Pitagorino stablo i šesterostrana prizma. Ostali elementi poput ljuljački i cvijeća dodani su kao slike preuzete s interneta. Napravljena je prezentacija po fazama realizacije projekta. Kroz rad na ovom projektu učenici su primjenjivali stečena znanja i vještine, ponajviše iz područja Matematike, Informatike i Tehničke kulture. Potrebno je više istraživanja o projektnoj nastavi u višim razredima osnovne škole kao i definirati projektnu nastavu u kurikulumu.
\end{abstract}

Ključne riječi: projekt; projektna nastava; suradničko učenje.

\section{Uvod}

U današnje vrijeme globalizacije, težnja suvremene nastave je poticati učenike na istraživački rad putem projektne nastave.

Nastavna strategija kao pristup kojim učitelj pristupa nastavnom procesu uvelike doprinosi uspješnosti ostvarenja obrazovnih ishoda. Strategije se razlikuju prema tome jesu li učenici aktivni ili pasivni sudionici i prema razini učiteljske kontrole. Sukladno tome razlikujemo predavačku strategiju, strategiju suradničkog učenja, strategiju samousmjerenog učenja i strategiju situacijskog učenja (Vizek-Vidović i sur., 2003). U literaturi, sinonimi za projekt i projektnu nastavu predstavljaju pojmovi: metoda, istraživačka nastava, problemska nastava.

Projekt je definiran kao zajednički pokušaj nastavnika i učenika da život, učenje i rad povežu tako da se društveno značajan i s interesima sudionika povezan problem zajednički obradi $i$ dovede do rezultata (Meyer, 2002), koji za sudionike odgojno obrazovnog procesa ima pozitivan ishod.

Projektna nastava je model organiziran oko projekta koja se temelji na problemskoj nastavi u kojoj 
učenici istražuju i uče sadržaj na autentičan način (Thomas, 2000). U suvremenom obrazovnom sustavu projektna nastava matematike i informatike postaje jedan od važnih oblika učenja i poučavanja. Klasična nastava matematike je ograničena kurikulumom, gdje je slabije prisutna korelacija s drugim predmetima $u$ obliku projektne nastave, kao i ograničen planirani fond godišnjih sati za realizaciju. Zbog toga se u praksi rijetko izlazi iz okvira uskih matematičkih sadržaja. Nedostaje povezanosti s realnim životom i primjerima iz svakodnevnog života, prevladavaju tradicionalni oblici nastave. Suvremena nastava matematike je usmjerena na učenika i uključuje partnerski odnos svih sudionika nastavnog procesa u obliku projektne nastave. Prevladavaju otvorenost prema problemskim zadacima, metode suvremenog timskog rada, razvijaju se organizacijske sposobnosti i osnove znanstvenog istraživanja kod učenika. Učitelj dobiva novu ulogu kao medijator, koordinator i partner što zahtijeva čvrsta didaktička i metodička znanja, razumijevanje suvremene nastavne strategije, kao i komunikacijske i organizacijske vještine (Tomljenović i Novaković, 2012). Učenicima se pruža mogućnost sudjelovanja u tehničkom i praktičnom obrazovanju, međusobne suradnje, timskog rada i komunikacije, što se smatra vještinama potrebnim za buduće zapošljavanje (Morgan, Jones, Barlex, 2013). Faze projekta prema Achiken i sur. (2002) obuhvaćaju: pronalazak teme, formuliranje ciljeva, planiranje i priprema projekta, ugovor, koordinacija, realizacija, dokumentacija, prezentacija, refleksija i evaluacija.

Maleš i Stričević (2009) navode sljedeće faze rada na projektu: izbor teme, priprema i plan istraživanja, odvijanje projekta, prezentacija i vrednovanje. Peko, Munjiza i Sablić (2007) navode ove faze: pronalaženje teme, formuliranje cilja i planiranje; prikupljanje podataka, obradu i analizu podataka te predstavljanje rezultata projekta; grupnu procjenu i samoprocjenu projektnog učenja. Tomljenović i Novaković (2012), Peko, Munjiza i Sablić (2007), Bognar i Matijević (2005) te Maleš i Stričević (2009) predlažu drugačije viđenje projektnih etapa. Sintezom je moguće izdvojiti da se svaki projekt mora sastojati od dogovora - postavljanja problema, realizacije - učeničkih projekata i evaluacije - procjene procesa i rezultata učenja.

Provedena su istraživanja projektne nastave $u$ svijetu. U Japanu je provedeno istraživanje o motivaciji za projektnom nastavom. $U$ ispitivanju je sudjelovalo 126 nastavnika i 631 učenika srednjih škola u Hong Kongu. Ispitivanje je pokazalo visoku intrinzičnu motivaciju nastavnika, što je rezultiralo i visokom motivacijom učenika (Lam Shui - fong i sur., 2009). U Turskoj su istraživanje proveli Isik i Gucum 2013. godine. Ispitivali su motivaciju učenika projektnom nastavom u znanosti i tehnologiji. Sudjelovalo je 75 učenika sedmih razreda. Rezultati su pokazali statističku značajnost u organizaciji, korištenju kognitivne strategije, unutarnjoj motivaciji. Nema brojnih istraživanja o stavovima učenika o projektnoj nastavi niti o rezultatima znanstvenih istraživanja o realizaciji projektne nastave u Republici Hrvatskoj. Žugaj (2014) je provela istraživanje o utjecaju projektne nastave na promjenu stava kod učenika iz biologije na uzorku od 108 učenika. Učenici koji su znanje usvajali projektnom nastavom, smatrali su gradivo zanimljivijim. Vidljiv je pozitivan napredak kod prosječnih učenika i učenika s nižom ocjenom. Nema razlike u učinkovitosti projektne nastave $s$ obzirom na spol.

Istraživanje o aktivnom učenju u kooperativnim skupinama provele su Buljubašić i Kuzmanović (2009). Rezultati su pokazali da svladavanje vještina aktivnog učenja i sudjelovanje u kooperativnim skupinama djeluje na jačanje motiviranosti i ustrajnosti, na odgovornost, komunikaciju, razvoj prijateljstva, produktivnost i djelotvornost.

Naše istraživanje je provedeno u III. osnovnoj školi Čakovec. Cilj istraživanja je bio ispitati stavove učenika o projektnoj nastavi. Nakon provedenog istraživanja koje je pokazalo da kod učenika postoji motiviranost za projektnom nastavom, dogovorena je suradnja učiteljica Matematike i Informatike i vođenje učenika kroz projekt Virtualni model modela školskog atrija. Projekt je realiziran u redovnoj nastavi Matematike i Tehničke kulture te izbornoj nastavi Informatike $s$ učenicima sedmih i osmih razreda. Očekuje se da će rezultati istraživanja doprinijeti afirmaciji projektne nastave $u$ području suvremenog odgoja i obrazovanja..

\section{Istraživanje o projektnoj nastavi u III. osnovnoj školi Čakovec}

U šk. godini 2018./2019. provedeno je istraživanje u III. osnovnoj školi Čakovec o stavovima učenika o projektnoj nastavi. Istraživanje je obuhvatilo sve dostupne učenike od 5. do 8. razreda ( $N=202)$.

Ispitivanje stavova učenika pokazalo je da projektna nastava prevladava u izbornim predmetima Informatike i Građanskog odgoja i obrazovanja koji je izborni predmet duži niz godina u 7. i 8. razredu. Percepcija učenika je da u redovnoj nastavi projektna nastava prevladava u premetu Tehnička kultura.

Nadalje, istraživanje je pokazalo da kod učenika viših razreda postoji motivacija za učenjem putem projektne nastave i da takva nastava učenike veseli ( $\mathrm{N}$ =202).

Slika 1 prikazuje motivaciju učenika za projektnu nastavu prema razredima predmetne nastave, pa je tako često ili uvijek motivirano za nastavu 90,7 \% učenika petih razreda, $80 \%$ učenika šestih razreda, 73,3 \% učenika sedmih razreda te 60,4 \% učenika 
osmih razreda $(p<0,01)$. Postoji trend smanjenja motivacije učenika za projektnu nastavu starije školske dobi. Najmanja je motivacija kod učenika osmih, a najveća kod učenika petih razreda.

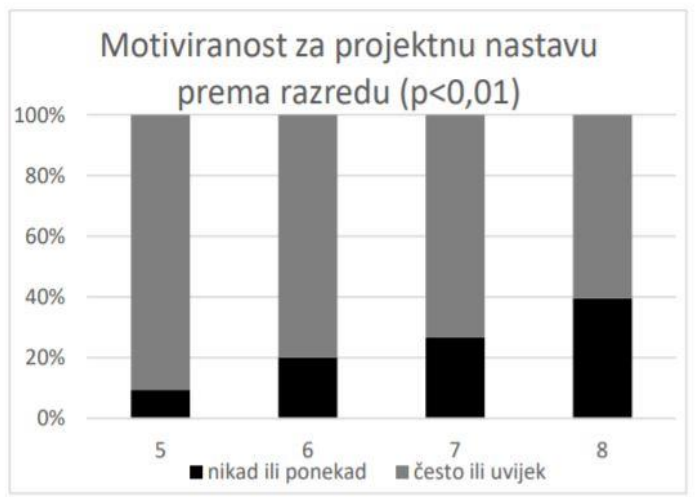

Slika 1. Motiviranost učenika od 5. do 8. razreda

Slika 2 prikazuje stavove učenika o projektnoj nastavi u nastavnom predmetu Informatika. Njihovo mišljenje je da je projektna nastava najmanje zastupljena u petom, a najviše u osmom razredu, što je zaista u skladu s praksom. Razlog tome je znatno viša razina znanja u poznavanju informacijskokomunikacijske tehnologije kod učenika osmih razreda, poznavanju većeg broja alata, većoj spremnosti za suradnjom ali i preuzimanjem odgovornosti za preuzete obaveze.

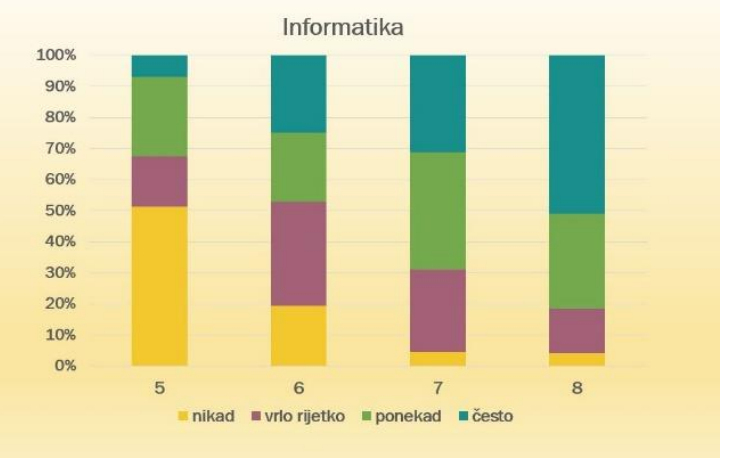

Slika 2. Stavovi učenika o projektnoj nastavi u nastavnom predmetu Informatika

Slika 3 prikazuje stavove učenika o projektnoj nastavi u nastavnom predmetu Matematika. Učenici smatraju da je projektna nastava više zastupljena u petom i šestom, u odnosu na sedmi i osmi razred, što također odgovara stanju u praksi. Razlog tome je zahtjevniji kurikulum u sedmom i osmom razredu, a samim time i nedostatak vremena za projektnom nastavom. $U$ petom i šestom razredu učenici nadograđuju postojeća znanja koja su stekli u nižim razredima osnovne škole i zato ostaje više vremena za realizaciju projekata.

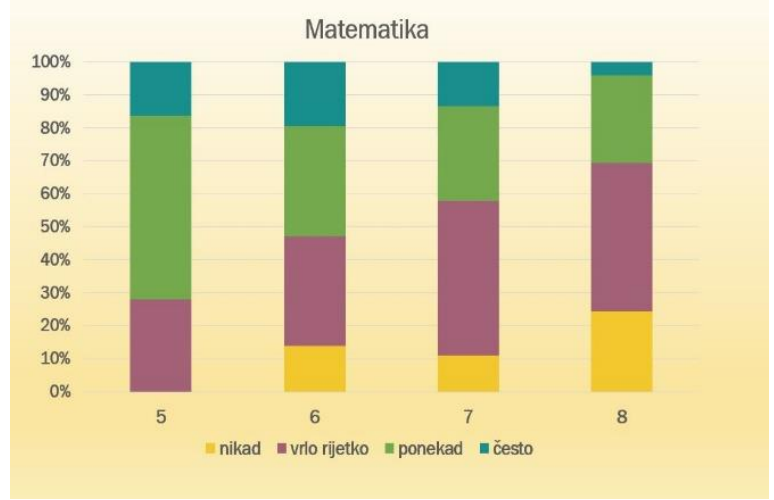

Slika 3. Stavovi učenika o projektnoj nastavi u nastavnom predmetu Matematika

Na slici 4 je vidljivo, prema stavovima učenika, da se projektna nastava u predmetu Tehnička kultura, više provodi u šestom i osmom razredu, dok je stanje u praksi da je projektna nastava više zastupljena $u$ petom nego u osmom razredu.

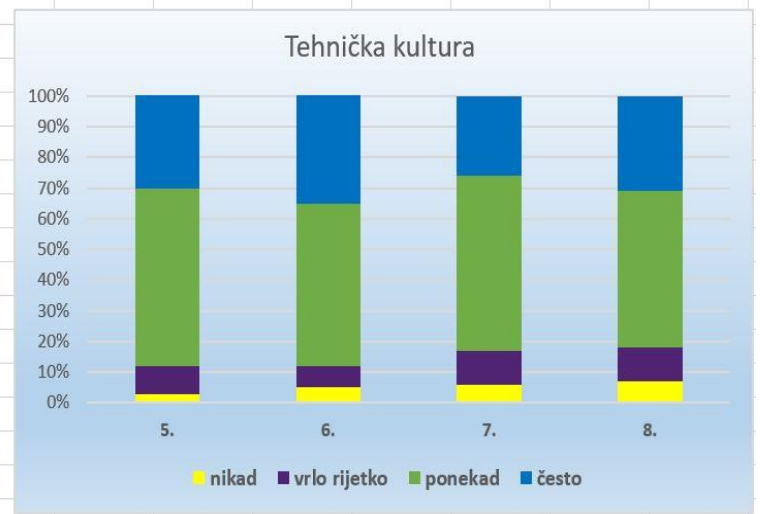

Slika 3. Stavovi učenika o projektnoj nastavi u nastavnom predmetu Tehnička kultura

\section{Projekt „Virtualni model školskog atrija“}

U dogovoru s učenicima definirana je tema projekta kao i plan realizacije. U projekt su bili uključeni učenici sedmih i osmih razreda $(N=108)$ III. osnovne škole Čakovec, školske godine 2018./2019. gdje su primjenjivali stečena znanja i vještine iz nastavnih predmeta Matematike, Informatike i Tehničke kulture. Cilj projekta je bio analizirati postojeće stanje školskog atrija, te izraditi novi model primjenom informacijsko-komunikacijske tehnologije.

Faze projekta su obuhvaćale: formiranje timova, podjelu zadataka, izradu snimke postojećeg stanja (foto zapis), uočavanje i prepoznavanje zelenih površina, staza, stepenica, sjenice, izračunavanje površina postojećih dijelova atrija, izradu tlocrta školskog atrija u umanjenim mjerilima, izradu digitalnog tlocrta u programu AUTODESK, izradu 
troškovnika za postojeće stanje. Izrađen je virtualni model novog atrija za koji su pojedini elementi izrađeni primjenom 3D modeliranja i to: Pitagorino stablo i šesterostrana prizma. Dodane su ljuljačke i cvijeće u obliku slika koje su preuzete s interneta. Napravljena je prezentacija po fazama realizacije projekta.

Učenici su izradili projektnu dokumentaciju: tlocrt školskog atrija u različitim mjerilima, troškovnik postojećeg školskog atrija u dokumentu Excel, digitalni model zamišljenog školskog atrija u programu 3D Paint i prezentaciju.

Učenički timovi su formirani u dogovoru s učenicima, prema njihovim interesima. U svakom timu su bila 4 učenika.

\subsection{Rezultati rada na projektu}

Učenici su izradili analizu postojećeg stanja atrija skicu atrija s određenim dijelovima kao sastavnim elementima istog i to: sveukupnu površinu, površinu bez kamenčića, stepenice, stazu, kućicu i travnati dio. Izvršena su sva potrebna mjerenja i napravljen analogni i digitalni tlocrt (slika 8). Izračunali su sve površine i to na analogni i digitalni način. Učenici su koristili program Ms Excel (slika 7 prikazuje izračun površine za stepenice i stazu od dasaka). Postojeći atrij zabilježili su fotoaparatom, (slika 5).

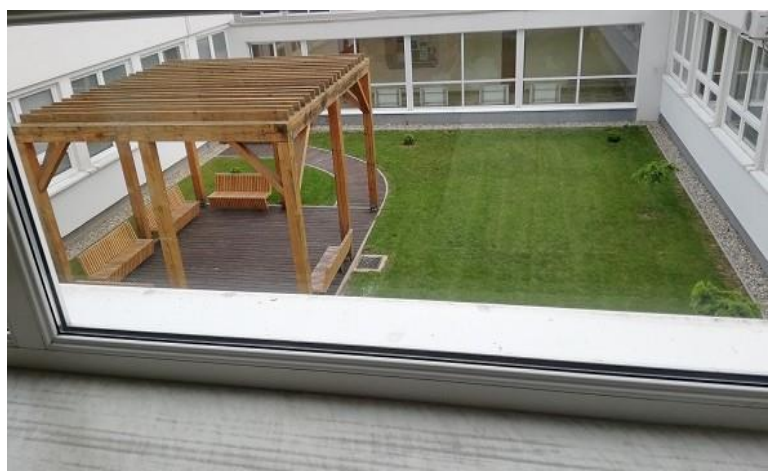

Slika 5. Postojeći atrij

Napravili su okvirni troškovnik postojećeg atrija za troškove pojedinih dijelova što se tiče materijala, bez usluga radova. $U$ tu svrhu trebali su pronaći materijale i cijene na internetu.

U virtualni model atrija dodani su neki novi dijelovi: Pitagorino stablo koje simulira bonsai stablo, cvijeće na prozore, ljuljačke, šesterostrana prizma koja može poslužiti kao mjesto gdje se može sjediti. Model zamišljenog bonsai drva učenici su izradili 3D modeliranjem i 3D ispisom i nazvali ga Pitagorino stablo. Zamišljeni model školskog atrija prikazuje slika 6.

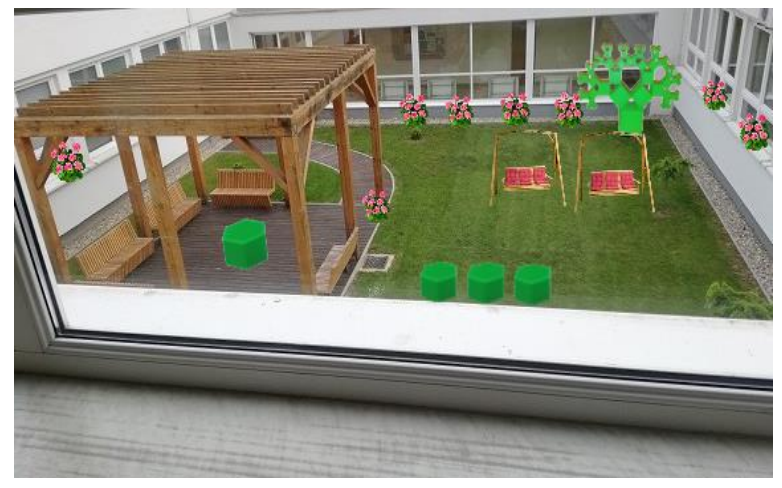

Slika 6. Virtualni atrij - zamišljeni model

Primijenili su poveznicu sa nastavnim gradivom iz matematike u 8. razredu, a to je Pitagorin poučak $i$ Geometrijska tijela. Pitagorin poučak glasi: Površina kvadrata nad hipotenuzom jednaka je zbroju površina kvadrata nad katetama. Pitagorin poučak pomaže u konstruiranju Pitagorina stabla. Ono nastaje tako da nad jednom stranicom kvadrata konstruiramo jednakokračni pravokutni trokut. Zatim se na njegove katete pridodaju novi kvadrati, a potom opet trokuti. Postupak će se ponavljati dok se ne dobije bonsai drvo.

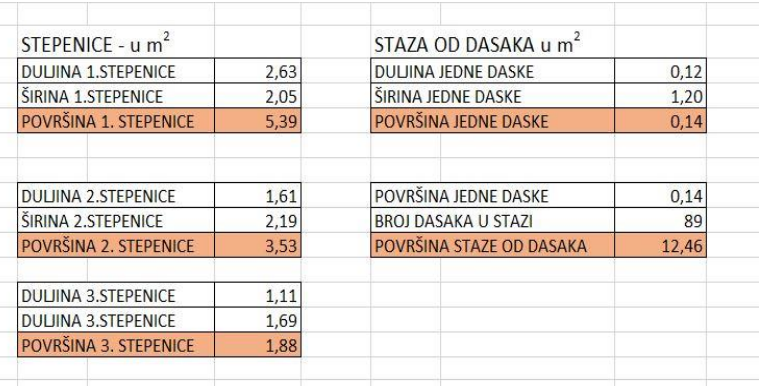

Slika 7. Primjer izračuna površine dijelova atrija primjenom tabličnog kalkulatora

Pitagorino stablo može biti simetrično i asimetrično. Učenici su na satu matematike radili na papiru geometrijsku konstrukciju Pitagorina stabla koristeći matematička znanja iz područja Kvadriranje i korjenovanje te Pitagorin poučak s ciljem približnog izgleda bonsai drva. Učenici su izradili simetrično Pitagorino stablo za virtualni školski atrij. Na satu informatike, učenici su 3D modeliranjem koristeći program 3D Studio Max napravili Pitagorino stablo i ispisali ga pomoću 3D pisača. 


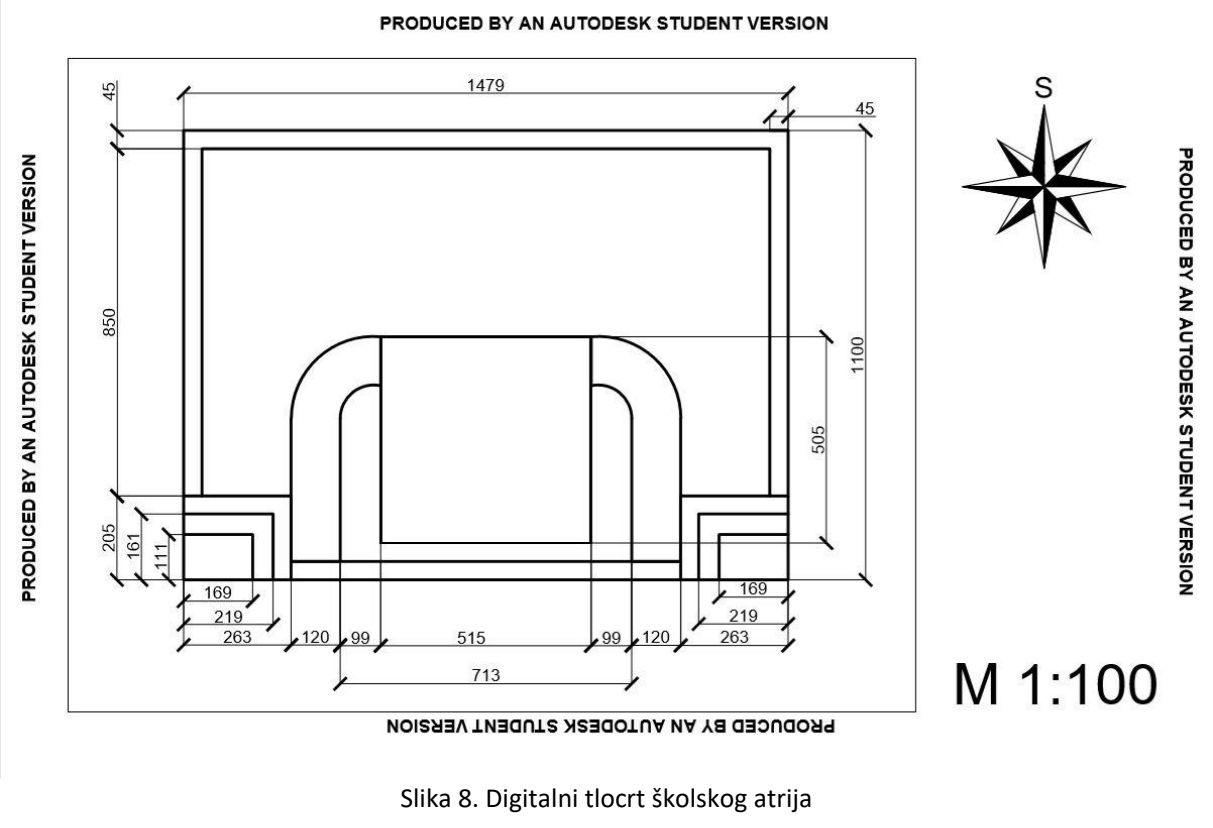

\section{Korelacija predmeta Matematika, Informatika i Tehnička kultura}

Vrijednost rada na ovom projektu, između ostalog, dolazi do izražaja u spoznaji učenika koliku prednost daje primjena informacijsko-komunikacijske tehnologije, prvenstveno u točnosti i brzini izvršavanja određenih zadataka. S druge strane, učenici uviđaju koliko su važna bazna, matematička znanja bez kojih sama primjena tehnologije nije dovoljna.

$\mathrm{U}$ tablici 1 prikazana je povezanost (korelacija) nastavnog sadržaja između predmeta Matematika, Informatika i Tehnička kultura. Uz to su navedeni ishodi učenja i aktivnosti kojima se takva korelacija podržava tijekom provedbe projekta.

\begin{tabular}{|c|c|c|c|}
\hline \multicolumn{2}{|c|}{ Matematika } & \multicolumn{2}{|c|}{ Informatika/Tehnička kultura } \\
\hline Tema & Ishod/Aktivnost & Tema & Ishod/Aktivnost \\
\hline $\begin{array}{l}\text { Prirodni brojevi } \\
\text { Decimalni brojevi }\end{array}$ & $\begin{array}{l}\text { Ishod: učenik prepoznaje } \\
\text { ravninu i prostor, učenik vrši } \\
\text { mjerenja metrom } \\
\text { odgovarajućoj mjernoj } \\
\text { jedinici } \\
\text { Aktivnost: učenik izračunava } \\
\text { površine postojećih dijelova } \\
\text { atrija (različiti četverokuti) - } \\
\text { ručno, na papiru } \\
\text { Ishod: učenik primjenjuje } \\
\text { osnovne računske radnje na } \\
\text { primjeru iz svakodnevnog } \\
\text { života izra } \\
\text { Aktivnost: učenik izrađuje } \\
\text { tlocrt postojećeg školskog } \\
\text { atrija u umanjenim mjerilima, } \\
\text { na papiru, crta rukom } \\
\text { Izrada troškovnika } \\
\text { postojećeg školskog atrija }\end{array}$ & $\begin{array}{l}\text { Osnovni izračuni u programu } \\
\text { za tablična računanja } \\
\text { Izrada tlocrta u programu } \\
\text { AUTODESK } \\
\text { Osnovni izračuni u programu } \\
\text { za tablična računanja }\end{array}$ & $\begin{array}{l}\text { Ishod: učenik prikuplja i unosi podatke } \\
\text { kojima se analizira neki problem s } \\
\text { pomoću odgovarajućega programa, } \\
\text { otkriva odnos među podatcima koristeći } \\
\text { se različitim alatima programa te } \\
\text { mogućnostima prikazivanja podataka } \\
\text { Aktivnost: Učenik izračunava površine } \\
\text { postojećih dijelova atrija primjenom } \\
\text { tabličnog kalkulatora } \\
\text { Ishod: učenik se koristi različitimalatima } \\
\text { programa te mogućnostima prikazivanja } \\
\text { podataka, učenik se koristi različitim } \\
\text { formatima zapisivanja } \\
\text { podataka na računalu } \\
\text { Aktivnost: učenik izrađuje digitalni tlocrt } \\
\text { postojećeg školskog atrija primjenom } \\
\text { studentske verzije programa AUTODESK } \\
\text { Ishod: učenik prikuplja i unosi podatke } \\
\text { kojima se analizira neki problem s } \\
\text { pomoću odgovarajućega programa, } \\
\text { otkriva odnos među podatcima koristeći } \\
\text { se različitim alatima programa te } \\
\text { mogućnostima prikazivanja podataka }\end{array}$ \\
\hline
\end{tabular}




\begin{tabular}{|c|c|c|c|}
\hline $\begin{array}{l}\text { Geometrijska tijela } \\
\text { Kvadriranje i korjenovanje }\end{array}$ & 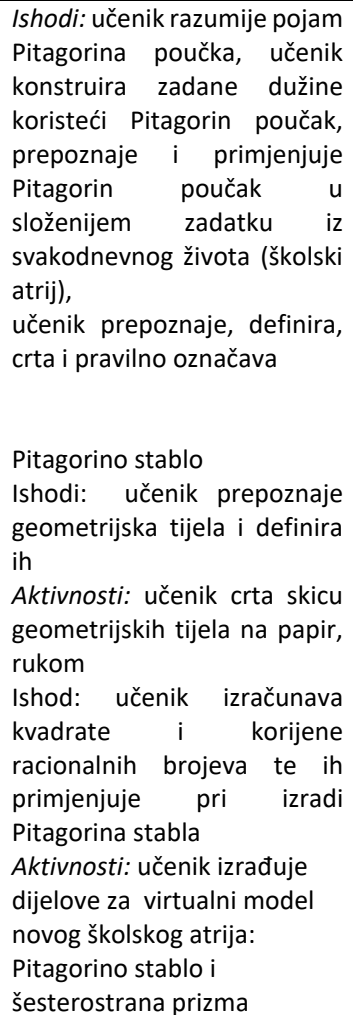 & $\begin{array}{l}\text { Primjena programa 3D Studio } \\
\text { Max } \\
\text { Ispis 3D modela 3D pisačem }\end{array}$ & $\begin{array}{l}\text { Aktivnost: učenik primjenom tabličnog } \\
\text { kalkulatora izrađuje troškovnik za } \\
\text { postojeći školski atrij } \\
\text { Ishod: učenik identificira neki problem iz } \\
\text { stvarnoga svijeta, stvara program za } \\
\text { njegovo rješavanje, dokumentira rad } \\
\text { programa i predstavlja djelovanje } \\
\text { programa drugima } \\
\text { Aktivnost: učenik osmog razreda } \\
\text { izrađuje 3D model Pitagorinog stabla } \\
\text { programom 3D Studio Max i 3D model } \\
\text { šesterostrane prizme i predstavlja } \\
\text { rješenje učenicima 7. razreda } \\
\text { Aktivnost: učenik ispisuje kreirane 3D } \\
\text { modele uporabom pisača Tronxy x5 (za } \\
\text { ispis Pitagorina stabla utrošeno je } 8 \text { sati } \\
\text { rada pisača) }\end{array}$ \\
\hline
\end{tabular}

Tablica 1. Povezanost predmeta Matematike, Informatike i Tehničke kulture s definiranim temama, ishodima i aktivnostima korištenih u realizaciji projekta

\section{Zaključak}

Po završetku rada na projektu, u neformalnom razgovoru s učenicima dobivena je povratna informacija od većine učenika, kako im se ovakav način rada (projektna nastava), više sviđa u odnosu na tradicionalni način. Osobna procjena većine učenika je da ranije stečena znanja mogu primijeniti u praksi.

Učitelj ima ulogu mentora i koordinatora. U realizaciji projekta učenici primjenjuju stečena znanja i vještine iz područja Matematike, Informatike i Tehničke kulture. Osim suradnje, do izražaja dolazi istraživanje, odgovornost za preuzete obveze. Sama priprema i realizacija projekta iziskuje za nastavnika znatno više vremena u odnosu na klasičnu nastavu. Učenicima je taj način rada zanimljiviji i više primjenjiv u svakodnevnom životu. Prisutna je intrinzična motivacija kod učenika i učitelja. Učenici usvajaju nove metode učenja gdje je do izražaja došla interdisciplinarnost obrazovnih ishoda.

Ispitani su stavovi učenika o projektnoj nastavi i realiziran je projekt „Virtualni model školskog atrija“. Ostvarene su sve faze projekta. Cilj projekta je analiza postojećeg stanja školskog atrija, te izrada novog modela primjenom informacijsko-komunikacijske tehnologije.

Primjenom znanja iz Matematike, Informatike i Tehničke kulture, digitalizirano je i postojeće i virtualno stanje atrija. U virtualni model atrija dodani su novi dijelovi: cvijeće na prozore, ljuljačke, šesterostrane prizme. Model zamišljenog bonsai drva je izrađen 3D modeliranjem i 3D ispisom.

Učenici su vrlo vješti u primjeni informacijsko komunikacijske tehnologije koju koriste za realizaciju samog projekta, ali i za međusobnu komunikaciju i suradnju učenika i učitelja. Ovaj primjer projektne nastave može poslužiti kao primjer dobre prakse.

\section{Literatura}

Achiken, I., Glogowatz, R., Großschmidt-Thierer, E., Pick, M., Schmidt, C., Weisz, C. (2002). Projektna nastava. Sarajevo: K-education.

Bognar, L., Matijević, M. (2005). Didaktika. Zagreb: Školska knjiga.

Buljubašić-Kuzmanović, V. (2009). Kooperativno učenje kao indikator kvalitete odgoja i obrazovanja. Život i škola, 21(1), 50-57.

Isik, O., Gucum, G. (2013). The Effect of Project Based Learning Approach on Elementary School Students' Motivation Toward Science and Technology Course. H. U. Journal of Education, 28(3), 206-218. 
Lam, S., Cheng, R. W., Ma, W. Y. K. (2009). Teacher and student intrinsic motivation in project-based learning. Instructional Science, 37(6), 565-578.

Maleš, D., Stričević, I. (2009). Rad na projektu: izazov za djecu i odrasle. Zagreb: Udruženje Djeca prva.

Meyer, H. (2002). Didaktika razredne kvake. Zagreb: Educa.

Miljković, D., Vizek-Vidović, V., Vlahović-Štetić, V., Rijavec, M. (2014). Psihologija obrazovanja. Zagreb: IEP.

Morgan, R., Jones, L., Barlex, D. (2013). New Principles for Design \& Technology in the National Curriculum, E4E. Preuzeto sa http://www.educationforengineering.org.uk/r eports/pdf/e4e_report_feb2013.pdf.

Peko, A., Munjiza, E., Sablić, M. (2007). Projektno učenje. Osijek: Sveučilište Josipa Jurja Strossmayera, Osijek.

Thomas, J. W. (2000). A Review of Research on Project. San Rafael, CA: Autodesk Foundation.

Tomljenović, Z., Novaković, S. (2012). Integrated teaching - a project in primary school elective art classes. Metodički obzori, 7(2012)1, 14, 119-134.

Vizek - Vidović, V. (2003). Psihologija obrazovanja. Zagreb: IEP.

Žugaj, B. Utjecaj projektne nastave na promjenu stava kod učenika prema nastavnim sadržajima iz biologije. Educatio biologiae, 2014., 1, 18 - 26.

\section{Virtual model of the school atrium}

\begin{abstract}
In the current globalization era, contemporary education has to take project-focused approach to teaching. Project was held in III OŠ ČK where visual model of the central school hall was designed, by implementing knowledge of subjects of Mathematics, Informatics and Technical Studies. Prior to the projects' start, survey has been held among students $(N=108, M=52 \%, F=48 \%)$ to gain insights into what their opinion is on practically oriented teaching in the School. Sample included the students of 5th, 6th, 7th and 8th grade. The survey results showed that students think project assignments are being done overall more within elective courses. While working on this particular project, students were able to apply knowledge of Mathematics, Informatics, as well as Technical studies. Specifically, students examined school hall's surfaces (grass / wood / stone). Students made calculations of hall surfaces for the purpose of making price list. Price list included costs of each material used, and was gathered though googling on Internet. Further, students using ICT assembled the virtual model of the school hall. By use of $3 D$ modelling, students made elements of the school hall - Pitagora's tree and a hexagonal prism. Other elements such as flowers have been added as photos downloaded from the internet. Subsequently, presentation following each project phase has been done. Further research is needed to gain deeper insights into practice-oriented assignments among students between grades 5 and 8. Recommendation is also to include projects/practical assignments as a compulsory part of curriculum.
\end{abstract}

Keywords: project, participial assignments, collaborative learning. 